\title{
Selective Localization of Radioiodinated Alkylphosphocholine Derivatives in Tumors
}

\author{
KATHLEEN P. PLOTZKE ${ }^{\prime}$, TERUSHI HARADAHIRA ${ }^{2}$, \\ LOUIS STANCATO ${ }^{1}$, NORMAN M. OLKEN ${ }^{2}$, SCOTT SKINNER ${ }^{4}$, \\ MILTON D. GROSS ${ }^{4}$, RICHARD L. WAHL ${ }^{3}$ and \\ RAYMOND E. COUNSELL ${ }^{1,2 *}$
} Departments of ${ }^{1}$ Pharmacology, ${ }^{2}$ Medicinal Chemistry and ${ }^{3}$ Internal Medicine. The University of
Michigan and ${ }^{4}$ Division of Nuclear Medicine, VA Medical Center, Ann Arbor, MI 48109, U.S.A.

(Receined 13 Fehruary 1992)

\begin{abstract}
We have designed and synthesized two radioiodinated analogs of hexadecylphosphocholine in order to evaluate their tumor imaging potential. 12-( $m\left[{ }^{125} I\right]$ iodophenyl)dodecyl phosphocholine (NM-324) and hexadecyl-2-[ $N, N$-dimethyl- $N$-( $m\left[{ }^{125} \mathrm{I}\right]$ iodobenzyl)-ammonium] ethyl phosphate (NM-326) demonstrated the ability of such compounds to localize in and thereby visualize the Walker 256 tumor in rats. However, the tumor avidity of NM-324 was far superior to NM-326. In addition, NM-324 showed excellent tumor localization in athymic mice bearing subcutaneous human tumors.
\end{abstract}

\section{Introduction}

Various strategies have been employed to achieve selective accumulation of a radiopharmaceutical within tumor cells. A particular problem associated with the currently available agents (e.g. $\left.\left[{ }^{67} \mathrm{Ga}\right] c \mathrm{itrate}\right)$ is poor tumor specificity (Merrick, 1984).

In order to achieve greater tumor specificity, numerous laboratories have explored the ability of tumor antibodies to serve as carriers for various radionuclides (Bejent, 1985; Pietersz et al., 1987; Eger et al., 1987; Woo et al., 1988). Studies in our own laboratory, on the other hand, have focused on drug molecules which have shown an ability to accumulate in tumors to serve as carriers of the radiodiagnostic probe (Counsell et al., 1969; Beierwaltes et al., 1968; Huang et al., 1979; Korn et al., 1979).

Several years ago we became interested in phospholipid ethers (PLEs) as a result of some pioneering studies by Fred Snyder and co-workers (Snyder and Wood, 1968, 1969). They found that PLEs, which are normally present in low concentration in tissues, accumulated in tumor cells as opposed to surrounding normal cells. Moreover, they provided evidence that this metabolic difference was at the site involving cleavage of the alkyl ether bond and that tumor cells as opposed to normal cells had very low concentrations of this alkyl cleavage enzyme. This metabolic

*All correspondence should be addressed to: Dr Raymond E. Counsell, M6322 Medical Science Building I, Department of Pharmacology, University of Michigan Medical School, Ann Arbor, MI 48109-0626, U.S.A. difference between neoplastic and normal cells suggested a means for selectively targeting drug molecules to tumors.

In addition, analogs of the naturally-occurring alkyl lysophospholipid are known to exhibit antitumor and antimetastatic activities. PLE, such as rac-1-octadecyl-2-methylglycero-3-phosphocholine (ET-18-OMe) (Fig. 1), have shown a selective cytotoxicity towards a variety of human and murine tumors in both in vivo and in vitro studies (Munder et al., 1981; Berdel et al., 1985). Similar antitumor activity has been shown for less complex structures known as alkylphosphocholines (APC) (Fig. 1) (Scherf et al., 1987; Muschiol et al., 1987). APC were developed to study the structure-activity relationship of alkyl lysophosphocholines as they may represent the minimal structural requirement for antitumor activity for such PLE-like compounds. In addition, hexadecylphosphocholine (He-PC), an APC, has been evaluated in a clinical pilot study in breast cancer patients with skin involvement. Tumor regression was seen when He-PC was applied topically (Unger et al., 1989). Based on these observations, regular phase I trial studies have been started. Despite earlier studies by Snyder and Wood (1968, 1969), the mechanism whereby PLEs accumulate in tumor cells is still unknown.

Based upon what is currently known about the accumulation of PLE-like molecules within cancer cells, a suitably radioiodinated PLE analog would be expected to concentrate within neoplastic cells and thereby allow visualization via scintigraphic imaging. Accordingly, a radioiodinated analog of 
<smiles>CCCCCCCCCCC(COC)COP(=O)([O-])OC</smiles>

ET-1 8-OMe

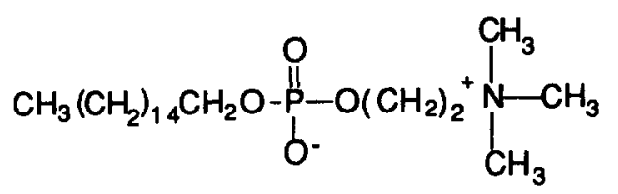

\section{Hexadecylphosphocholine}

Fig. 1. rac-1-Octadecyl-2-methylglycero-3-phosphocholine (ET-18-OMe) and hexadecylphosphocholine (He-PC).

the naturally-occurring alkyl lysophospholipid was synthesized for evaluation as a potential tumorlocalizing imaging agent. $r a c-1-[12-(m-$ Iodophenyl)dodecyl]-2-methylglycero-3-phosphocholine (NM-294) (Fig. 2) (Meyer et al., 1989) was radiolabeled with iodine-125 via an isotope exchange procedure. Tissue distribution studies with NM-294 in rats bearing the Walker 256 carcinosarcoma clearly demonstrated its ability to accumulate in the tumor. Although radioactivity was also present in non-target tissues at this time, clearance of tracer from the tumor was much slower and thus provided a suitable tumor to nontarget tissue ratio at $24 \mathrm{~h}$. As a result of this selective accumulation. it was possible to clearly delineate the tumor using $\gamma$-camera scintigraphy.

In order to assess the structural relationships required for optimal tumor localization, the alkyl-

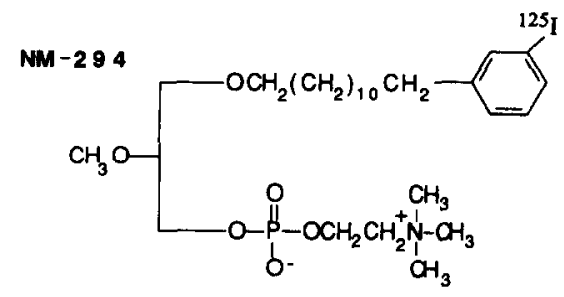

NM-324<smiles>C[N+](C)(C)CCOP(=O)([O-])OCCCCCc1cccc(I)c1</smiles>

NM-326

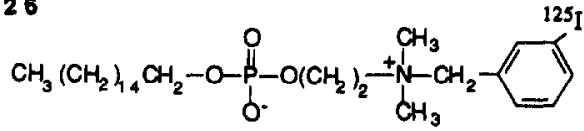

Fig. 2. rac-1-[12-(m-Iodophenyl)dodecyl]-2-methylglycero3-phosphocholine (NM-294), 12-(m-iodophenyl)docecyl phosphocholine (NM-324) and hexadecyl-2[ $N, N$-dimethyl$N(m$-iodobenzyl)ammonium]ethylphosphate (NM-326). phosphocholine analogs 12-( $m\left[{ }^{125} I\right]$ iodophenyl $)-$ dodecyl phosphocholine (NM-324) and hexadecyl2-[N,N-dimethyl- $N$-( $m\left[{ }^{125} \mathrm{I}\right]$ iodobenzyl) ammonium] ethylphosphate (NM-326) were synthesized (Fig. 2). This paper describes the synthesis and evaluation of these agents as potential tumor-localizing agents.

\section{Materials and Methods}

Syntheses of $m$-iodophenyl derivatives of $\mathrm{He}-\mathrm{PC}$

Preparation of 12-(m-iodophenyl)dodecylphosphocholine (3). To an ice-cooled solution of 12( $m$-iodophenyl)dodecanol (1) (Meyer et al., 1989) $(110 \mathrm{mg}, 0.28 \mathrm{mmol})$ in dry $\mathrm{Et}_{2} \mathrm{O}(2 \mathrm{~mL})$ containing $\mathrm{Et}_{3} \mathrm{~N}(0.05 \mathrm{~mL}, 0.36 \mathrm{mmol})$ was added dropwise 2-bromoethyl dichlorophosphate ( $83 \mathrm{mg}, 0.34 \mathrm{mmol}$ ) in dry $\mathrm{Et}_{2} \mathrm{O}(1.5 \mathrm{~mL})$. The mixture was stirred at $0^{\circ} \mathrm{C}$ for $10 \mathrm{~min}$ and was gently refluxed for $3 \mathrm{~h}$. Additional dichlorophosphate $(68 \mathrm{mg})$ and $\mathrm{Et}_{3} \mathrm{~N}(0.04 \mathrm{~mL})$ were added and the refluxing was continued for an additional $3 \mathrm{~h}$. Water $(1 \mathrm{~mL})$ was added and the mixture was refluxed for $2 \mathrm{~h}$. After removal of the solvents, the residue was dissolved in $\mathrm{CHCl}_{3}$. The $\mathrm{CHCl}_{3}$ was washed with $\mathrm{H}_{2} \mathrm{O}, 0.1 \mathrm{~N} \mathrm{HCl}$ and $\mathrm{H}_{2} \mathrm{O}$, dried and evaporated to dryness. The resulting residue was chromatographed on silica gel first with $\mathrm{CHCl}_{3}: \mathrm{MeOH}(15: 1)$ to remove less polar impurities, then with $\mathrm{CHCl}_{3}: \mathrm{MeOH}(8: 1)$ to elute pure intermediate $2(101 \mathrm{mg}, 62 \%)$ as a glassy solid, which was used for the next step without further purification.

A mixture of $2(101 \mathrm{mg}, 0.18 \mathrm{mmol})$ and $\mathrm{Me}_{3} \mathrm{~N}$ (1.3 $\mathrm{mL}, 45-50 \%$ aqueous soln) in $\mathrm{CHCl}_{3}$ : DMF :2$\operatorname{PrOH}(3: 5: 5)(10 \mathrm{~mL})$ was stirred at $60^{\circ} \mathrm{C}$ for $6 \mathrm{~h}$. After cooling, silver carbonate $(63 \mathrm{mg})$ was added to the mixture and the mixture was heated for $2 \mathrm{~h}$. The silver salts were removed by filtration with Celite and the filtrate was concentrated to dryness. The residue was chromatographed on silica gel first with $\mathrm{CHCl}_{3}: \mathrm{MeOH}(3: 1)$ to remove starting material (23 mg), and then with $\mathrm{CHCl}_{3}: \mathrm{MeOH}: \mathrm{H}_{2} \mathrm{O}$ $(65: 25: 3)$ to elute pure $3(59 \mathrm{mg}, 61 \%)$ as a white solid. ' $\mathrm{H}$-NMR $\delta: 7.52(1 \mathrm{H}, \mathrm{s}, \mathrm{Ar}-2 \mathrm{H}), 7.49(1 \mathrm{H}, \mathrm{d}$, Ar $-4 \mathrm{H}), 7.12(1 \mathrm{H}, \mathrm{d}, \mathrm{Ar}-6 \mathrm{H}), 6.99(1 \mathrm{H}, \mathrm{t}, \mathrm{Ar}-5 \mathrm{H})$, $4.29\left(2 \mathrm{H}\right.$, bs, $\left.-\mathrm{CH}_{2} \mathrm{CH}_{2} \mathrm{~N}\right), 3.86-3.75(4 \mathrm{H}, \mathrm{m}$, $\left.-\mathrm{CH}_{2} \mathrm{OPOCH}_{2} \mathrm{~N}\right), 3.39\left(9 \mathrm{H}, \mathrm{s}, \mathrm{N}(\mathrm{Me})_{3}\right), 3.26$ (bs, $\left.\mathrm{H}_{2} \mathrm{O}\right), 2.52\left(2 \mathrm{H}, \mathrm{t},-\mathrm{CH}_{2} \mathrm{P}\right)$. Anal. calcd for $\mathrm{C}_{23} \mathrm{H}_{41} \mathrm{INO}_{4} \mathrm{P} \cdot \mathrm{H}_{2} \mathrm{O}: \mathrm{C}, 48.34 ; \mathrm{H}, 7.58 ; \mathrm{N}, 2.45$. Found: C, 48.09; H, 7.71; N, 2.45.

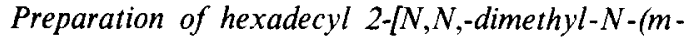
iodobenzyl)ammonium Jethylphosphate (5). To an icecooled solution of hexadecanol $(500 \mathrm{mg}, 2.06 \mathrm{mmol}$ ) in dry $\mathrm{Et}_{2} \mathrm{O}(15 \mathrm{~mL})$ containing $\mathrm{Et}_{3} \mathrm{~N}(0.36 \mathrm{~mL}$, $2.60 \mathrm{mmol}$ ) was added dropwise 2-bromoethyl dichlorophosphate $(600 \mathrm{mg}, 2.48 \mathrm{mmol})$ in dry $\mathrm{Et}_{2} \mathrm{O}$ $(10 \mathrm{~mL})$. The mixture was stirred at $0^{\circ} \mathrm{C}$ for $10 \mathrm{~min}$ and was gently refluxed for $4.5 \mathrm{~h}$. After cooling, water $(3.5 \mathrm{~mL})$ was added and the mixture was heated at $60^{\circ} \mathrm{C}$ for $2 \mathrm{~h}$. The solvents were removed under reduced pressure and the resulting residue was dissolved in $\mathrm{CHCl}_{3}$. The $\mathrm{CHCl}_{3}$ was washed with $\mathrm{H}_{2} \mathrm{O}$, 
$0.1 \mathrm{~N} \mathrm{HCl}$ and $\mathrm{H}_{2} \mathrm{O}$, dried and evaporated to dryness. The residue was chromatographed on silica gel first with $\mathrm{CHCl}_{3}: \mathrm{MeOH}(15: 1)$ and then with $\mathrm{CHCl}_{3}: \mathrm{MeOH}(8: 1)$ to give pure intermediate 4 (Hansen et al., 1982) (376 mg, 43\%) as a white solid, which was used without further purification. A mixture of $4(100 \mathrm{mg}, 0.23 \mathrm{mmol})$ and $N, N$-dimethyl$m$-iodobenzylamine $(304 \mathrm{mg}, 1.16 \mathrm{mmol})$ in $\mathrm{EtOH}$ $(5 \mathrm{~mL})$ was refluxed for 3 days and then for $2 \mathrm{~h}$ in the presence of $\mathrm{Ag}_{2} \mathrm{CO}_{3}(83 \mathrm{mg})$. After removal of the silver salts by filtration, the filtrate was concentrated to dryness under reduced pressure. The resulting residue was chromatographed on silica gel with $\mathrm{CHCl}_{3}: \mathrm{MeOH}(3: 1)$ to give pure $5(41.5 \mathrm{mg}, 29 \%)$ as a white solid. ${ }^{1} \mathrm{H}-\mathrm{NMR} \delta: 7.91(1 \mathrm{H}, \mathrm{s}, \mathrm{Ar}-2 \mathrm{H})$, $7.77(1 \mathrm{H}, \mathrm{d}, \mathrm{Ar}-4 \mathrm{H}), 7.69(1 \mathrm{H}, \mathrm{d}, \mathrm{Ar}-6 \mathrm{H}), 7.15$ $(1 \mathrm{H}, \mathrm{t}, \quad \mathrm{Ar}-5 \mathrm{H}), 4.89\left(2 \mathrm{H}, \mathrm{s},-\mathrm{CH}_{2} \mathrm{Ph}\right), \quad 4.40$ $\left(2 \mathrm{H}, \quad\right.$ bs, $\left.-\mathrm{CH}_{2} \mathrm{CH}_{2} \mathrm{~N}\right), \quad 3.86-3.80(4 \mathrm{H}, \quad \mathrm{m}$, $\left.-\mathrm{CH}_{2} \mathrm{OPOCH}_{2} \overline{\mathrm{CH}}_{2} \mathrm{~N}\right), 3.29\left(6 \mathrm{H}, \mathrm{s}, \mathrm{N}(\mathrm{Me})_{2}\right) 2.77$ (bs, $\left.\mathrm{H}_{2} \mathrm{O}\right), 1.55\left(2 \mathrm{H}, \mathrm{m},-\mathrm{CH}_{2} \mathrm{OP}-\right), 1.25(26 \mathrm{H}, \mathrm{s}$, $\left.-\left(\mathrm{CH}_{2}\right)_{13}\right), 0.88\left(3 \mathrm{H}, \mathrm{t},-\overline{\mathrm{CH}}_{2} \mathrm{CH}_{3}\right)$. Anal. calcd for $\mathrm{C}_{27} \overline{\mathrm{H}}_{49} \mathrm{INO}_{4} \mathrm{P} \cdot \mathrm{H}_{2} \mathrm{O}: \mathrm{C}, 51.68 ; \mathrm{H}, 8.19 ; \mathrm{N}, 2.23$. Found: C, 51.92; H, 8.35; N, 2.15.

\section{Radioiodination by iodine exchange}

Radioiodination of 3 and 5 with iodine-125 was accomplished by the same method as for the preparation of NM-294 reported previously (Counsell et al., 1990). Briefly, the compound (1-2 mg) to be labeled was treated with $\mathrm{Na}^{125} \mathrm{I}(1.3-3 \mathrm{mCi})$ in pivalic acid $(15 \mu \mathrm{L})$ at $160^{\circ} \mathrm{C}$ for $45 \mathrm{~min}$. The radioiodinated product was purified by silica gel column chromatography $(1 \times 5 \mathrm{~cm})$. A solvent mixture of $\mathrm{CHCl}_{3}: \mathrm{MeOH}: \mathrm{H}_{2} \mathrm{O}(65: 25: 4)$ was used to elute 3, whereas $\mathrm{CHCl}_{3}: \mathrm{MeOH}(1: 1)$ was used for elution of 5. Radiochemical purity of the isolated product was established by radio-TLC with unlabeled material serving as standard. Radiochemical yields based on TLC of exchange reaction mixture was 66 and $72 \%$ for 3 and 5, respectively.

\section{Animals}

Female Sprague-Dawley rats, 200-250 g (Charles River, Portage, Mich.) were housed in a temperature and light-controlled room and had free access to food and water. The rats were inoculated with Walker 256 carcinosarcoma cells $\left(1.0 \times 10^{7}\right.$ cells $)$ in saline in the left and/or right hindlimb. These animals were used 7-10 days later when the tumor weight averaged $10 \mathrm{~g}$. Athymic nude mice, 20-25 g (Charles River, Wilmington, Del.) were housed in specific pathogenfree rooms and had free access to food and water. The mice were inoculated subcutaneously into the shoulder region with human carcinoma cells $\left(1.0 \times 10^{7}\right.$ cells $)$. These animals were used when the tumors were approx. $5 \mathrm{~mm}$ in diameter. The time to reach this tumor size varied with the different cell lines. For example, HTB-63 (human melanoma) and NCI-H69 (human small cell carcinoma of the lung) cells required 4-6 weeks for tumor growth whereas, HTB-77 (human ovarian carcinoma) took 10-14 days.

\section{Cell lines and culture conditions}

The Walker 256 cell line was provided by Dr James Varani of the Department of Pathology, University of Michigan. The cells were maintained in RPMI 1640 medium containing $10 \%$ fetal bovine serum (FBS), 200 units $/ \mathrm{mL}$ of penicillin, and $0.2 \mathrm{mg} / \mathrm{mL}$ of streptomycin. HTB-63 (human melanoma), NCI-H69 (human small cell carcinoma of the lung) and HTB77 (human ovarian carcinoma) cells were purchased from ATCC (American Type Tissue Culture Collection). HTB-63 cells were maintained in McCoy's 5a medium plus $10 \%$ FBS. NCI-H69 and HTB-77 cells were maintained in RPMI 1640 plus $10 \%$ FBS. In addition, medium for the human cell lines contained penicillin/streptomycin (final concentration of $50 \mu \mathrm{g}$ penicillin $/ \mathrm{mL}$ and $50 \mu \mathrm{g}$ streptomycin $/ \mathrm{mL}$ ) and L-glutamine, $200 \mathrm{mM}$ (final concentration of $292 \mu \mathrm{g} / \mathrm{mL}$ ). All cells were maintained at $37^{\circ} \mathrm{C}$ in a humidified atmosphere of $90 \% \mathrm{~N}_{2}, 5 \% \mathrm{CO}_{2}$ and $5 \% \mathrm{O}_{2}$.

\section{Tissue distribution}

The radiolabeled compounds were dissolved in $95 \% \mathrm{EtOH}$ and Tween-20 (0.1 mL/mg of compound $)$ was added. The solvent was evaporated with a stream of nitrogen. Physiological saline was added, and the final traces of solvent were removed by passing nitrogen over the solution until it became clear (in final solution $2-3 \%$ Tween). The solubilized radiolabeled compound $(15-35 \mu \mathrm{Ci}$, rats: $0.5-1.0 \mathrm{~mL}$, mice: $0.1 \mathrm{~mL}$ ) was administered i.v. via a tail vein to tumor-bearing animals. The rats were sacrificed by exsanguination and the mice by decapitation while under ether anesthesia at the various time points. The blood was collected and selected tissues were removed and blotted of excess blood. Large organs were minced with scissors. Tissue samples were weighed in cellulose acetate capsules and counted with a Searle 1185 well scintillation counter $(85 \%$ counting efficiency). The concentration of radioactivity in each tissue was expressed as percentage of administered dose per gram of tissue.

\section{Lipid extraction}

Samples of liver, plasma and tumor were homogenized in $\mathrm{CHCl}_{3}: \mathrm{MeOH}$ by the method of Folch et al. (1957). Briefly, $0.1 \mathrm{~g}$ tissue or $0.1 \mathrm{~mL}$ plasma and $0.4 \mathrm{~mL}$ water were homogenized in three washes of $3 \mathrm{~mL}$ each of $\mathrm{CHCl}_{3}: \mathrm{MeOH}(2: 1)$ and the resulting homogenate filtered. The filter paper was air-dried and assayed for radioactivity. The filtrate was adjusted to $10 \mathrm{~mL}$ with $\mathrm{CHCl}_{3}: \mathrm{MeOH}$, an additional $2 \mathrm{~mL} \mathrm{H}_{2} \mathrm{O}$ was added and centrifuged for $10 \mathrm{~min}$ at $800 \mathrm{~g}$. The aqueous and organic phases were separated. The aqueous phase was adjusted to $5 \mathrm{~mL}$ with 
$\mathrm{CHCl}_{3}: \mathrm{MeOH}: \mathrm{H}_{2} \mathrm{O}(3: 48: 47)$ and a $1 \mathrm{~mL}$ aliquot was taken for counting. The organic phase was evaporated under nitrogen, then redissolved in $1 \mathrm{~mL}$ of benzene. A $0.1 \mathrm{~mL}$ aliquot was taken for counting and the remainder was sealed and stored overnight. The benzene fraction was dried, then the compound resuspended in diethyl ether and spotted on a silica gel $60 \mathrm{~F}-254$ thin layer chromatography (TLC) plate (Eastman Kodak, Rochester, N.Y. or Merck, Darmstadt). After allowing the plates to air dry, they were developed in $\mathrm{CHCl}_{3}: \mathrm{MeOH}: \mathrm{HOAc}: \mathrm{H}_{2} \mathrm{O}$ $(75: 25: 8: 3)$ (NM-324) and $\mathrm{CHCl}_{3}: \mathrm{MeOH}(1: 2)$ (NM-326). After removal from the developing tank, the plates were allowed to air dry, then scanned using a System 200 Imaging Scanner. The radioactivity appearing in the lipid extract is expressed as \% of total radioactivity present on the filter, and both in the aqueous and organic phase.

\section{Gamma-camera imaging of rats and mice}

Scanning of the animals was done with an Ohio Nuclear Mobile Camera with a high sensitivity-low energy collimator. Animals were sedated with $87 \mathrm{mg} / \mathrm{kg}$ ketamine and $13 \mathrm{mg} / \mathrm{kg}$ xylazine. Images were accumulated at various time points following administration of radiolabeled compound (35-75 $\mu \mathrm{Ci})$.

\section{Results and Discussion}

12-( $m$-Iodophenyl)dodecylphosphocholine (3, NM$324)$ and hexadecyl-2-[ $N, N$-dimethyl- $N$-( $m$-iodobenzyl)ammonium] ethylphosphate (5, NM-326) were synthesized as shown in Fig. 3. 12-( $\mathrm{m}$-Iodophenyl)dodecanol (1) was prepared by the procedure reported previously (Meyer et al., 1989). Phosphorylation of both 1 and hexadecanol with 2-bromoethyl dichlorophosphate gave 12 -( $m$-iodophenyl dodecyl2-bromoethylphosphate (2) and hexadecyl-2-bromoethylphosphate (4) in 62 and $43 \%$ yield, respectively. The phosphate (2) was readily converted to the choline phosphate (3) in $62 \%$ yield by heating with trimethylamine in $\mathrm{CHCl}_{3}: 2$-PrOH:DMF $(3: 5: 5)$ for $6 \mathrm{~h}$. Condensation of the phosphate 4 and $m$-iodobenzylamine was carried out by refluxing in $\mathrm{EtOH}$ for 3 days to give $N$-iodobenzyl derivative 5 in $29 \%$ yield.

To evaluate the potential of NM-324 and NM-326 as tumor localizing agents, scintigraphic images were obtained at various time points following injection as shown in Fig. 4. Administration of NM-324 to a rat bearing a Walker carcinosarcoma in the hind limbs produced excellent images of the tumors. A high background activity was seen in the abdominal area at the early time points with subsequent clearing.

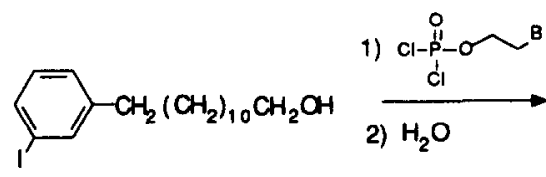

1

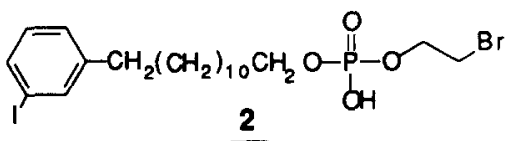

2

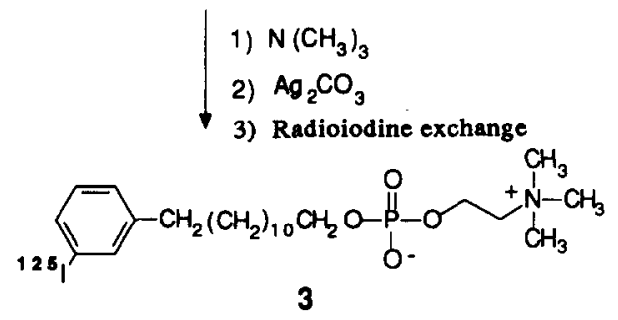

$\mathrm{H}_{3} \mathrm{C}\left(\mathrm{CH}_{2}\right)_{14} \mathrm{CH}_{2} \mathrm{OH}$<smiles>O=[PH](=O)(O)OCCBr</smiles>

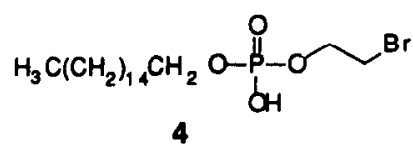<smiles>CCCCOC(=O)OCC[N+](C)(C)OCc1cccc(C)c1</smiles>

Fig. 3. Synthesis of radioiodinated analogs of alkylphosphocholine, NM-324 and NM-326. 


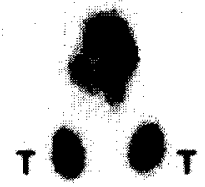

$24 h$

Acquisition time $4.1 \mathrm{~min}$

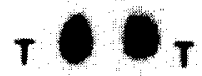

$120 \mathrm{~h}$ Acquisition time $5.9 \mathrm{~min}$

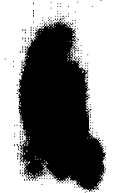

$32 \mathrm{~h}$

Acquisition time $6.2 \mathrm{~min}$

$120 \mathrm{~h}$

Acquisition time $120 \mathrm{~min}$

Fig. 4. Gamma-camera scintigraphy at various time periods following administration of NM-324 and NM-326 of rats bearing Walker 256 tumors implanted in the thighs. The dose administered and the timle to accumulate 100,000 counts are shown. 
NM-324 in athymic mice bearing human tumors

\section{Ovarian carcinoma}
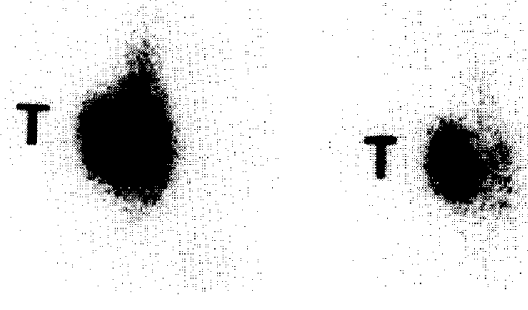

Small cell carcinoma
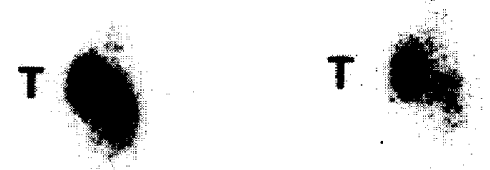

\section{Melanomo}

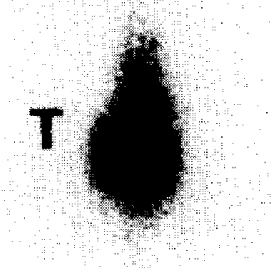

Doy 5

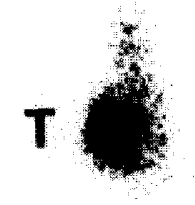

Day 8
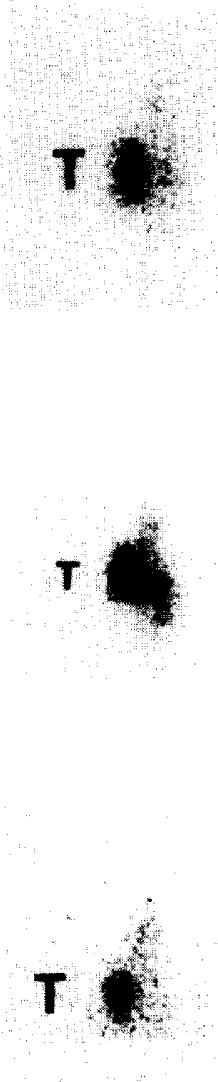

Doy 12

Fig. 7. Gamma-camera scintigraphy of athymic mice bearing human tumors at 5,8 and 12 days following administration of NM-324. The dose administered was $30 \mu \mathrm{Ci}$. 


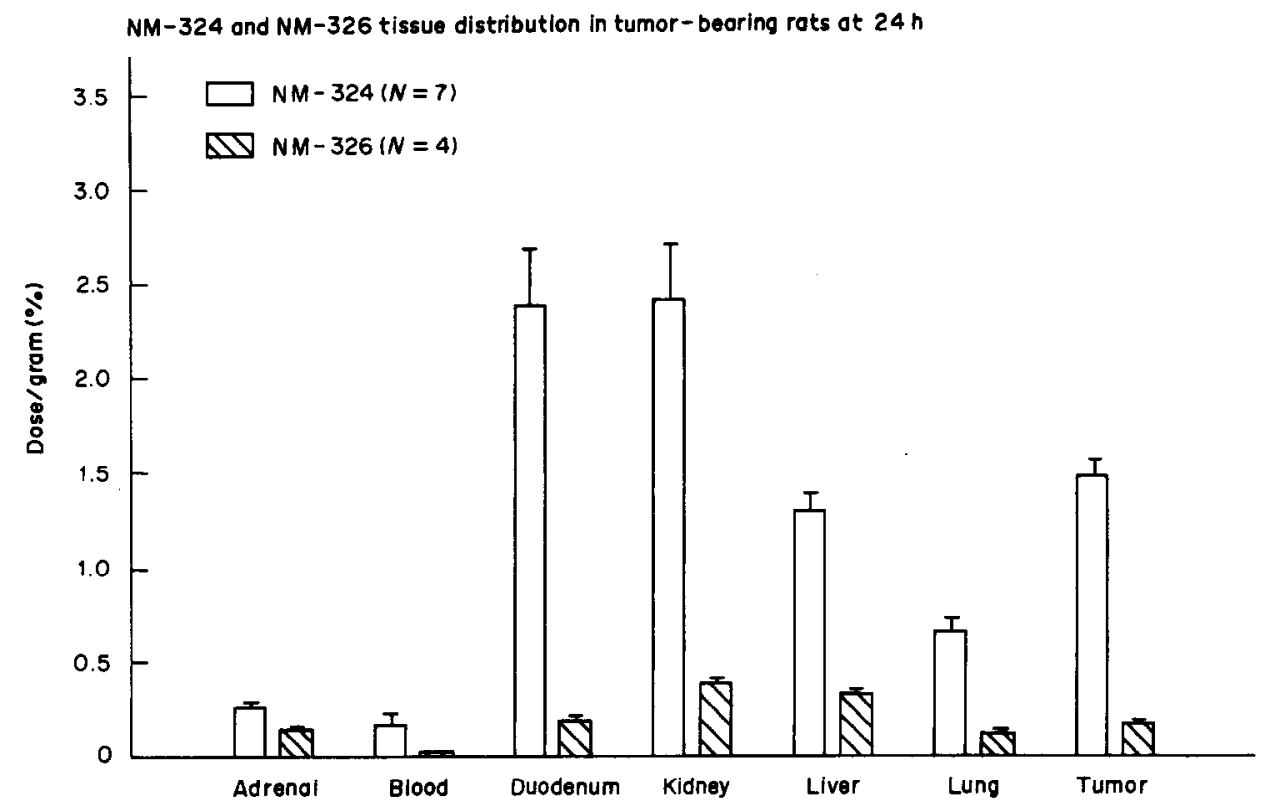

Fig. 5. Distribution of radioactivity following i.v. administration of radioiodinated analogs in tumorbearing rats at $24 \mathrm{~h}$. The dose administered was $15 \mu \mathrm{Ci}$.

NM-326 also produced good images of the tumors, but had even higher background activity. In addition, a comparison of the image acquisition time for the two compounds showed that NM-326, at a dose of $85 \mu \mathrm{Ci}$, took longer to acquire 100,000 counts than NM-324 at a smaller dose of $58 \mu \mathrm{Ci}$ (Fig. 4). This suggested that the NM-326 was being rapidly cleared from the animal while NM-324 was being retained by the tumor.

Tissue distribution studies with NM-324 in the rat bearing the Walker tumor at $24 \mathrm{~h}$ post-injection demonstrated the tumor to accumulate $10.5 \%$ of the dose. On the other hand, only $2 \%$ of the dose of NM-326 was taken up by the tumor at $24 \mathrm{~h}$ (Fig. 5). In addition, NM-326 showed minimal uptake of radioactivity in all tissues. Earlier time points (data not shown) for NM-326 showed high levels of radioactivity in liver, duodenum and kidneys with subsequent clearing by $24 \mathrm{~h}$. Most of the radioactivity appeared to be eliminated shortly after injection. NM-324 also showed (Fig. 6) high levels of radioactivity in the duodenum, kidneys and liver which

NM-324 tissue distribution in tumor-bearing rots at various time points post injection

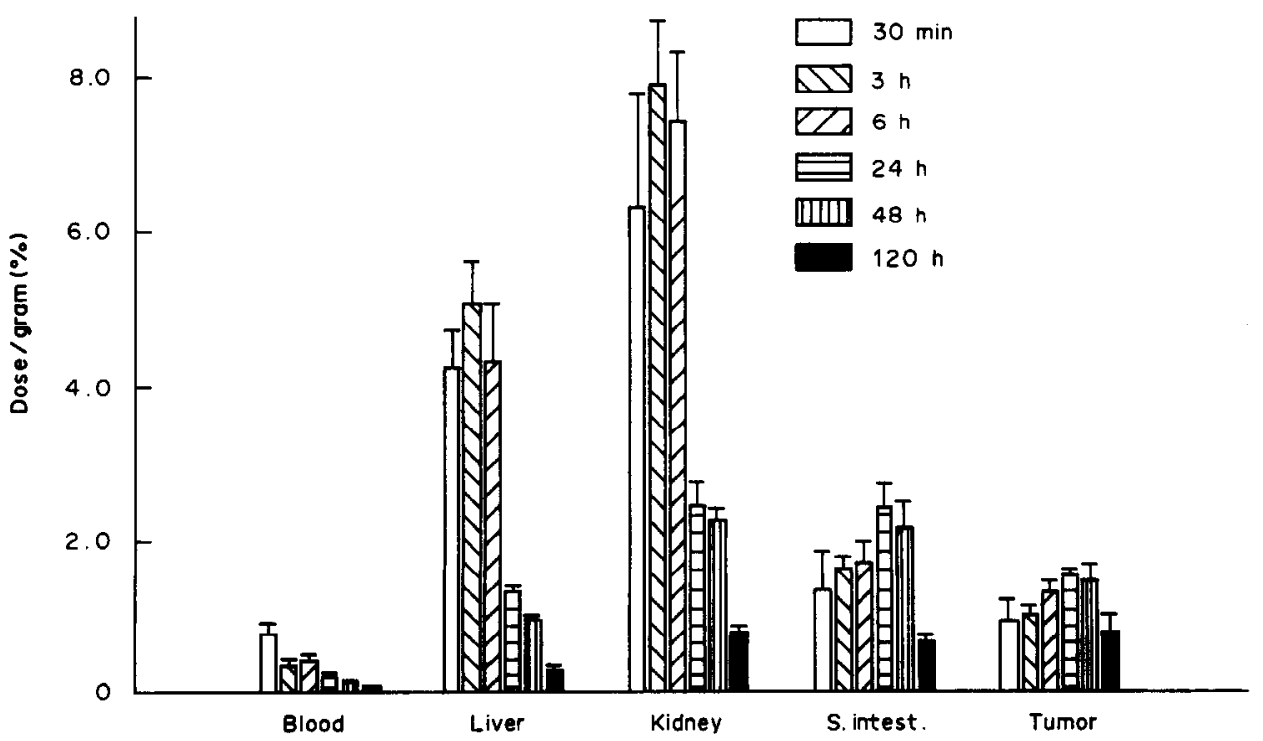

Fig. 6. Distribution of radioactivity of NM-324 in the tumor-bearing rat at various time periods following administration. 
Table 1. Lipid soluble radioactivity extracted from rat liver, plasma and tumor following i.v. administration of NM-324 and NM-326

\begin{tabular}{lcc}
\hline & \multicolumn{2}{c}{$\% \mathrm{CHCl}_{3} / \mathrm{CH}_{3} \mathrm{OH}$} \\
extractable
\end{tabular}

declined with time. Clearance of radioactivity from the tumor, however, was much slower with tumor radioactivity peaking at $48 \mathrm{~h}$.

These encouraging results with NM-324 prompted further evaluation in athymic mice bearing subcutaneous human tumors such as the HTB-63 (melanoma), NCI-H69 (small cell carcinoma of the lung) and HTB-77 (ovarian carcinoma). Gammacamera scintigraphy at 5 days post-injection showed tumor localization with a high backgound activity. By 8 and 12 days the background activity had cleared from the liver and GI tract leaving clear images of the tumors (Fig. 7). Tissue distribution data obtained on these mice following the last day of scanning showed tissue/blood levels $>25 / 1$ in all three models (data not shown).

Lipid extraction of the liver from tumored rats at $3,6,24,48 \mathrm{~h}$ and 5 days (NM-324) and 3,6 and $24 \mathrm{~h}$ (NM-326) demonstrated that most of the radioactivity present was lipid extractable (Table 1). Thin layer chromatography of the organic phases at 24 and $120 \mathrm{~h}$ showed that most of the radioactivity remained associated with the parent compound for NM-324 in the liver and tumor (Fig. 8). There was a much lower level of lipid extractable radioactivity from the

In vivo metobolism of $\mathrm{NM}-324$ in tumor-bearing rats at 24 and $120 \mathrm{~h}$
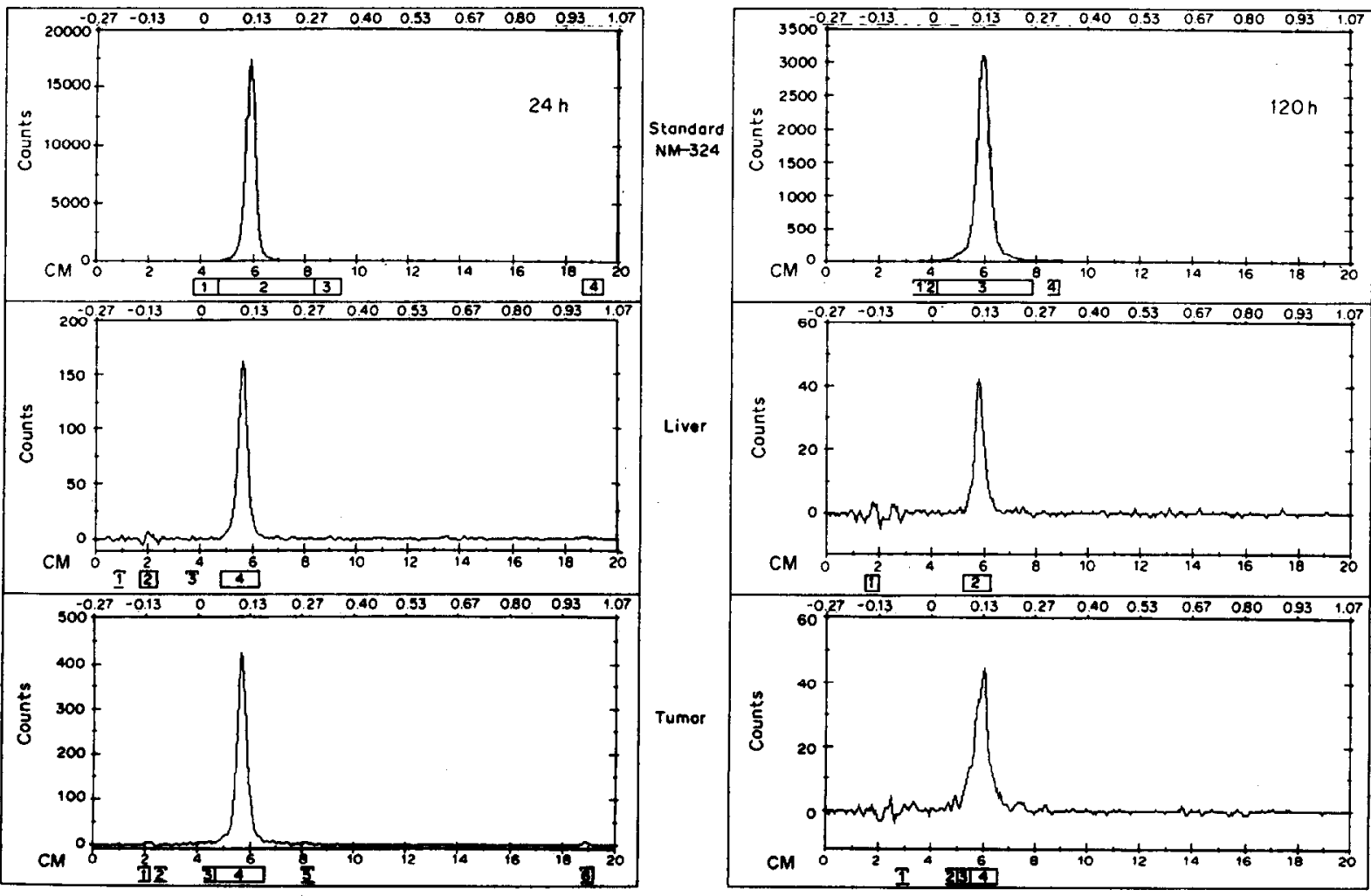

Fig. 8. Thin layer chromatography of parent compound and lipid extracts of liver and tumor from rats bearing a Walker 256 tumor at 24 and $120 \mathrm{~h}$ following administration of NM-324. The solvent system used was $\mathrm{CHCl}_{3}: \mathrm{MeOH}: \mathrm{HOAc}: \mathrm{H}_{2} \mathrm{O}(75: 25: 8: 3)$. The origin was at $4.0 \mathrm{~cm}$ and the solvent front at $17 \mathrm{~cm}$. Pure radiolabeled compound used for administration was employed as the reference standard. 
plasma suggesting clearance of the radioactivity over time.

With NM-326 the percent of radioactivity associated with the parent compound remained stable over time in the liver and tumor tissue. This coupled with the fact that nondetectable levels were seen in the plasma suggested that the parent compound was cleared from the animal fairly rapidly.

Based on these studies with two structural analogs of APC, it is clear that certain structural features are required for optimal retention of these molecules in tumors. In contrast to NM-324, NM-326 showed poor accumulation in the Walker 256 carcinosarcoma tumor. Basically these compounds differ only by the placement of the iodophenyl marker moiety. Placement of this group on the choline portion of the molecule markedly altered the ability to localize in the tumor. Other investigators have shown that alteration of this portion of the molecule either by replacing with a phosphoinositol group (Noseda et al., 1987) or by lengthening the carbon chain (Schick et al., 1987) causes a decrease in tumor cytotoxicity.

In summary, radioiodinated analogs of APC represent a new class of agents whose excellent tumor uptake suggests that they may have potential clinical use not only as noninvasive tumor imaging agents but also as candidates for tumor therapy.

Acknowledgements - The authors wish to thank Dr James Varani of the Department of Pathology for providing the Walker 256 carcinosarcoma cells and Ms Eddie Quenby for her technical assistance with the tissue distribution studies. The authors also wish to express their appreciation to Ms Alice Sannes and Mr Mark Rampy for their technical assistance with the preparation of the manuscript. Support for this research was provided by the National Institute of Health grant (CA-08349) and the Rackham School of Graduate Studies Research Partnership Fellowship.

\section{References}

Beierwaltes W. H., Varma V. M., Lieberman L. M., Counsell R. E. and Morales J. D. (1968) Scintillation scanning of malignant melanoma with radioiodinated quinoline derivatives. J. Lab. Clin. Med. 72, 485-494.

Bejent R. H. J. (1985) Recent advances in tumor imaging. Use of radiolabeled antitumour antibodies. Biochim. Biophys. Acta 780, 151-166.

Berdel W. E., Andreesen R. and Munder P. G. (1985) Phospholipids and Cellular Regulation (Edited by Kuo J. F.), pp. 41-73. CRC Press, Boca Raton, Fla.

Counsell R. E., Pocha P., Ranade V. V., Sterngold J. and Beierwaltes W. H. (1969) Tumor localizing agents VII. Radioiodinated quinoline derivatives. J. Med. Chem. 12, 232-236.

Counsell R. E., Schwender S. W., Meyer K. L., Haradahira T. and Gross M. D. (1990) Tumor visualization with a radioiodinated phospholipid ether. J. Nucl. Med. 31, 332-336.
Eger R. R., Covell D. G., Carrasquillo J. A., Abrams P. G., Foon K. A., Reynolds J. C., Schroff R. W., Morgan A. C., Larson S. M. and Weinstein J. N. (1987) Kinetic model for the biodistribution of an "II In-labeled monoclonal antibody in humans. Cancer Res. 47, 3328-3336.

Folch J., Lees M. and Sloane Stanley G. H. (1957) A simple method for the isolation of total lipides from animal tissues. J. Biol. Chem. 226, 497-509.

Hansen W. J., Murari R., Wedmid Y. and Baumann W. J. (1982) An improved procedure for the synthesis of choline phospholipids via 2-bromoethyl dichlorophosphate. Lipids 17, 453.

Huang C. C., Korn N. and Counsell R. E. (1979) Potential organ- or tumor imaging agents. 18 Radioiodinated diamines and bisquaternaries. J. Med. Chem. 22, 449-452.

Korn N., Huang C. C., Seevers R. H., Rothwell C. and Counsell R. E. (1979) Bisquaternary ammonium compounds as potential tumor imaging agents. Int. J. Nucl. Med. 6, 153-161.

Merrick M. V. (1984) Tumors and soft tissues. In Essentials of Nuclear Medicine, pp. 249-268. Churchill-Livingstone, Edinburgh, U.K.

Meyer K. L., Schwendner S. W. and Counsell R. E. (1989) Potential tumor or organ-imaging agents. 30 Radioiodinated phospholipid ethers. J. Med. Chem. 32, 2142-2147.

Munder P. G., Modolell M., Bausent W. P., Oettgen H. F. and Westphal O. (1981) Augmenting Agents in Cancer Therapy (Edited by Hersh E. M., Chirigos M. A. and Mastrangelo M. J.), pp. 441-458. Raven Press, New York.

Muschiol C., Berger M. R., Schuler B., Scherf H. R., Garzon F. T., Zeller W., Unger C., Eible H. J. and Schahl D. (1987) Alkylphosphocholines: toxicity and anticancer properties. Lipids 22, 930-934.

Noseda A., Berens M. E., Piantadosi C. and Modest E. J. (1987) Neoplastic cell inhibition with new ether lipid analogs. Lipids 22, 878-883.

Pietersz G. A., Kanellas S., Smyth M. J., Zalcberg J. and McKenzie I. F. C. (1987) The use of monoclonal antibody conjugates for the diagnosis and treatment of cancer. Immun. Cell Biol. 65, 111-125.

Scherf H. R., Schuler B., Berger M. R. and Schmahl D. (1987) Therapeutic activity of ET-18-0 $\mathrm{CH}_{3}$ and hexadecylphosphocholine against mammary tumors in BD-VI rats. Lipids 22, 927-929.

Schick H. D., Wolfgang B. E., Fromm M., Fink U., Jehn U., Ulm K., Reichert A., Eibl H., Unger C. and Rastetter J. (1987) Cytotoxic effects of ether lipids and derivatives in human neoplastic bone marrow cells and leukemic cells in vitro. Lipids 22, 904-910.

Snyder F. and Wood R. (1968) The occurrence and metabolism of alkyl and alk-1-enyl ether of glycerol in transplantable rat and mouse tumors. Cancer Res. 28, 972-978.

Snyder F. and Wood R. (1969) Alkyl and alk-1-enyl ethers of glycerol in lipids from normal and neoplastic human tissue. Cancer Res. 29, 251-257.

Unger C., Damenz W., Fleer E. A., Kim D. J., Breiser A., Hilgard P., Engel J., Nagel G. and Eible H. J. (1989) Hexadecylphosphocholine, a ncw ether lipid analogue. Studies on the antineoplastic activity in vitro and in vivo. Acta Oncol. 28, 213-217.

Woo D. V., Markoe A. M., Brady L. W., Koprowski C., Koprowski H., Heindel N. and Mattis (1988) Am. J. Clin. Oncol. 11, 355-361. 